\title{
Experimental Investigation of Interface Behaviour of Different Types of Granular Soil/Geosynthetics
}

\author{
Awdhesh Kumar Choudhary ${ }^{1}$ A. Murali Krishna ${ }^{2}$
}

Received: 3 October 2015/Accepted: 6 January 2016/Published online: 22 January 2016

(C) Springer International Publishing Switzerland 2016

\begin{abstract}
In this paper, influence of different types of soils and geosynthetics on soil/geosynthetics interface behaviouris investigated by direct shear and pullout tests. Three different types of cohesionless soils and three different types of geosynthetics materials are adopted for experimental investigation. A series of large direct shear tests and pullout tests were conducted to investigate the interface behaviour of soil/geosynthetics. The test equipment, soils, and geosynthetics properties are described. The influence of soil particle size $\left(D_{50}\right)$ and geosynthetic structure are discussed by analysing tests results. Results are presented and discussed in terms of peak shear resistance, peak pullout resistance, interface friction angle, efficiency factors and interaction coefficient for different soils and geosynthetics. It could be seen that the interface friction angle from both direct shear and pullout tests linearly increases with increase in $\left(D_{50}\right)$ of soil. The pullout interaction coefficients $\left(\mathrm{C}_{i}\right)$ are found to be in the range of 0.62-1.72 for different tests conditions.
\end{abstract}

Keywords Direct shear test - Pullout test - Sand . Geosynthetics · Efficiency factor - Interaction coefficient

Awdhesh Kumar Choudhary

awdhesh@iitkgp.ac.in

A. Murali Krishna

amurali@iitg.ernet.in

1 IIT Kharagpur, Kharagpur, India

2 IIT Guwahati, Guwahati, India

\section{Introduction}

Soil reinforcement techniques are adopted to enhance the performance of earth structures like: reinforced walls, soft ground improvement, roads and railways embankments, slope stabilization and foundations etc. Any geosynthetic material employed as reinforcement has the main task of resisting applied stresses or preventing unacceptable deformations in reinforced geotechnical structures. In this process, the geosynthetic acts as tensioned member to the composite material (soil and fill material) and restrain tensile deformations by mobilizing tensile load in geosynthetic and to stop the soil from sliding over the geosynthetic or pulling out the soil by providing bond resistance, adhesion, interlocking or confinement and thus maintains the stability of the soil mass [1-3].

The evaluation of soil/geosynthetic interface behaviour is very important for design and analysis of geosynthetic reinforced soil structures $[4,5]$. Generally, cohesionless soils are preferred as the backfill soil/neighbouring soil for geosynthetics in reinforced soil structures. These materials have been the preferred backfill material due to their high strength and ability to prevent development of pore water pressure [6]. The interface friction angle and adhesion between a geosynthetic and soil are the primary and the most contentious variables used in design and stability analysis of geosynthetic reinforcement structures.

Modified direct shear and pullout tests are performed to provide the design engineer with the friction angle, adhesion coefficient and other design parameters for various interfaces within the design. ASTM D5321 [7] standard on direct shear test method is commonly followed for the purpose. The dimensions of typical direct shear test specimen $300 \times 300 \mathrm{~mm}$. Though the shear strength of the soil/geosynthetic interface has been investigated by 
conducting other tests, such as tilt-table tests $[8,9]$, the direct shear test is still the most common testing method [10-13]. The interface shear resistance of soil against geomembrane or geotextiles comes from the friction between soil and geosynthetic, because soil particles are not trapped into the small openings of geosynthetics. Pullout tests method commonly performed in accordance with ASTM D6706 [14] to provide the design parameters, which can be used in the design of geosynthetic-reinforced retaining walls, slopes, and embankments or in other applications where resistance of a geosynthetic to pullout under simulated field condition is important. Thus, a safe and economic design of soil reinforcement requires a good understanding of interaction mechanisms that develop between the soil and the reinforcement [15-17]. The interactions can be simplified as soil sliding in direct shear over the reinforcement and pullout of reinforcement from the soil [18]. The pullout mechanism has been investigated by full-scale and laboratory model tests and numerical analysis [19-28]. These studies mostly investigated geosynthetic/granular soil interactions. The literature indicate that the soil-geosynthetic interaction is complex as it is affected by structural, geometrical, and mechanical characteristics of the soil and geosynthetic, as well as by boundary and loading conditions.

Almost all previous investigations have studied the behaviour of geosynthetics in one type of granular soil. Very few researchers have investigated the shear behaviour of different types of soils and geosynthetics [8, 29]. The objective of this paper is to investigate the influence of different types of soils and geosynthetics on soil/geosynthetic interface parameter from both direct shear and pullout tests. For the experimental investigation, different cohesionless soils having different gradation curves, mean/effective particle sizes are selected along with different types of geosynthetics. The Results are presented and discussed in terms of peak shear resistance, peak pullout resistance, interface friction angle, efficiency factors and interaction coefficient, describing the influence of different types of soils and geosynthetics.

\section{Test Equipment and Procedures}

\section{Direct Shear Test}

A large direct shear test setup, with a shear box of size $300 \mathrm{~mm} \times 300 \mathrm{~mm} \times 150 \mathrm{~mm}$ height, as shown in Fig. 1 was used to evaluate the interaction behaviour of the soil/geosynthetic systems. The direct shear tests on geotechnical materials (soil-soil) were conducted according to ASTM D3080 [30]. Modified direct shear tests on soil-geosynthetic specimens were conducted according to ASTM D5321 [7], in a manner similar to a direct shear test on geotechnical materials but with a modification. The

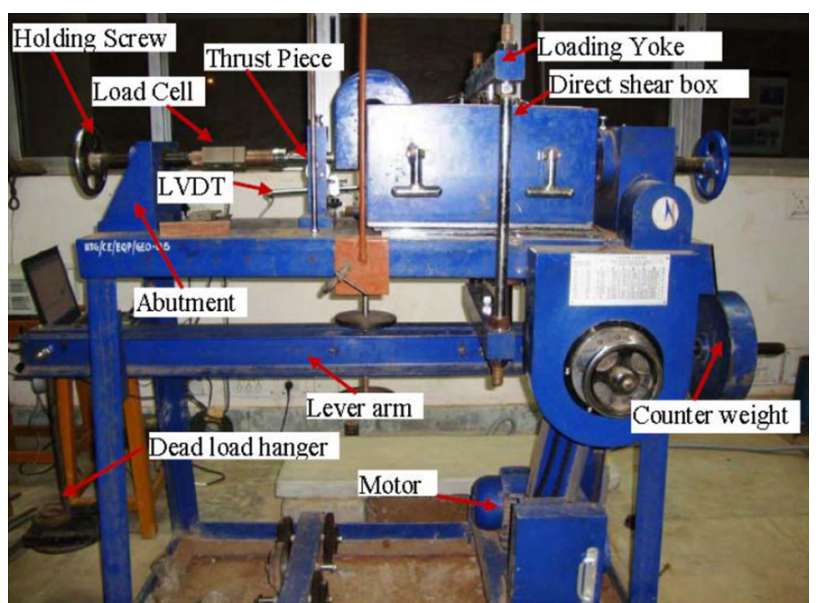

Fig. 1 Large direct shear box setup

modification is that the lower shear box of the conventional direct shear test setup was fitted with rigid wooden block and a wooden plank of dimensions $295 \mathrm{~mm} \times 295 \mathrm{~mm}$ covered/clamped with geotextile was placed on the wooden block (Fig. 2). The use of similar rigid block was practiced by Lee and Manjunath [11] and Lopes and Silvano [31]. The lower box of direct shear test setup could able to move for $35 \mathrm{~mm}$ of total displacement during shearing. The normal load was applied through a loading yoke connected to a loading lever, counter-balanced by a dead weight. The shearing of the test specimen was done by a screw-advanced drive system, powered by a motor and gear system, maintaining a controlled constant rate of shear displacement. During shearing, the lead screw pushes the shear box along with the lower half box, such that the load cell connected to the upper half of the box via the U-arm measures the shear resistance. Horizontal displacement is recorded by placing a linear variable differential transformer (LVDT) onto the front face of the shear box as shown in Fig. 1. During testing, data from the load cell and LVDT were recorded through data acquisition system.

\section{Pullout Test}

Pullout tests were performed in accordance with ASTM D 6706 [14]. Modified direct shear test setup (Prashanth and
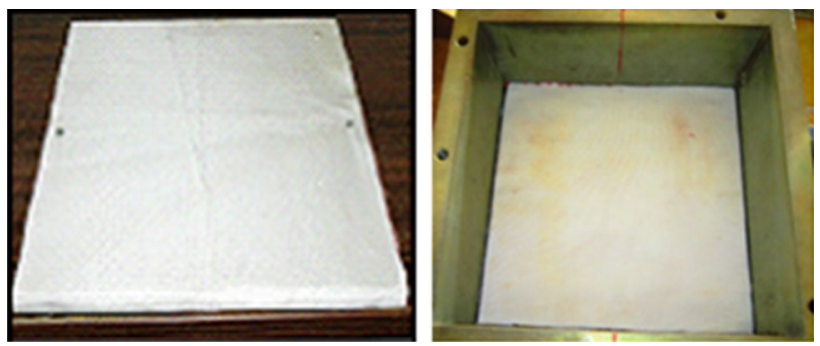

Fig. 2 Modification to the direct shear box 
Krishna [32]) was used for conducting the pullout tests. The modification was the replacement of direct shear box with a pullout box (Fig. 3) of with inner dimensions of

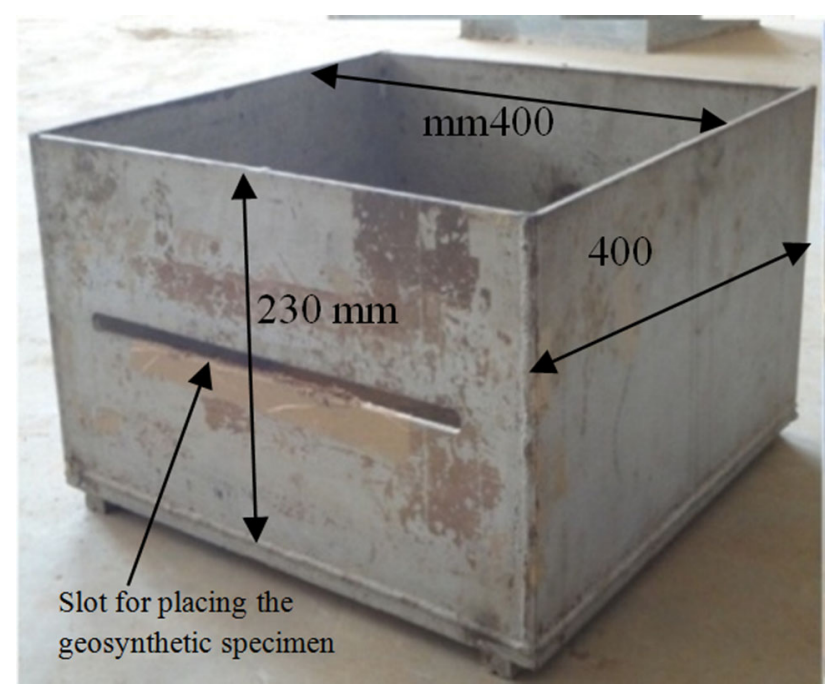

Fig. 3 Pullout box

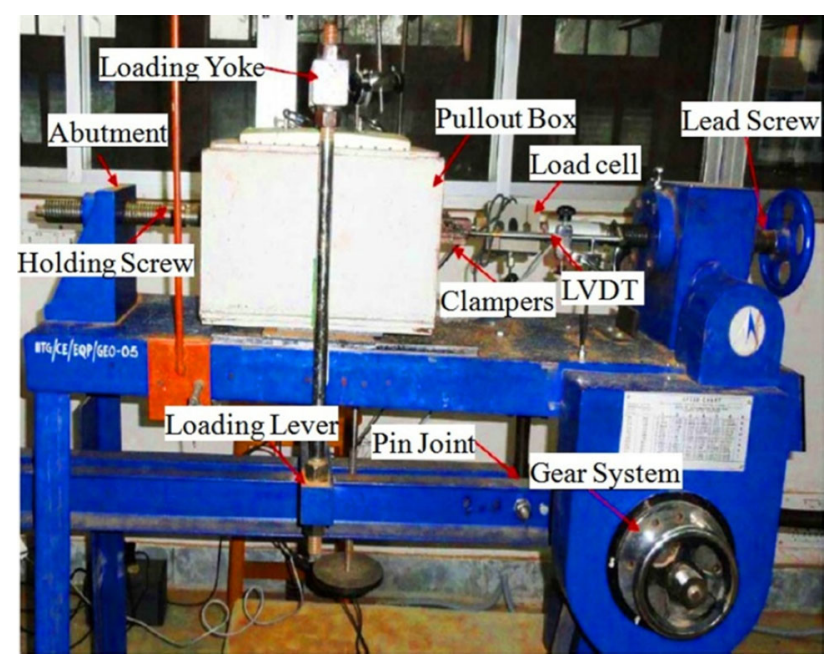

Fig. 4 Modified pullout test setup (after Prashanth and Krishna [36])
$400 \mathrm{~mm}$ long, $400 \mathrm{~mm}$ wide and $230 \mathrm{~mm}$ height and having a $12 \mathrm{~mm}$ thick horizontal slot for placing the geosynthetic specimen in the soil. A picture of the pullout test setup arrangement and associated instrumentation is shown in Fig. 4. The sand was placed to the desired level and the clamped testing specimen (Fig. 5) was inserted through the slot and then further pluviation of sand was continued till the top of box. The displacement of geosynthetic was measured by a LVDT that was placed on to the geosynthetic clamper. The other end of the clamper was connected to a load cell that was further fixed to a screw-advance drive system. The pull is applied to the clamped geosynthetic specimen by means of lead screw the motor gear drive system of the direct shear test setup as shown in Fig. 4. After having arranged all, the vertical or normal load was applied through a loading yoke connected to a loading lever. The clamped geosynthetic was allowed to pull at constant strain rate. Friction between the soil and inner walls of the box was minimized by pasting a smooth thin plastic sheet over the inner walls of the box. Displacement by means of a LVDT and the pull-out load through the load cell were acquired using data acquisition system.

\section{Materials Used}

\section{Soils}

Three different types of cohesionless soils were used in the tests. The particle size distributions, as per ASTM D6913 [33], of the three types of soils: soil 1, soil 2 and soil 3 are shown in Fig. 6. Their physical properties such as maximum dry density, minimum dry density and specific gravity of soil were determined according to ASTM D4253 [34], ASTM D4254 [35] and ASTM D 0854 [36], respectively, and are presented in Table 1 . The specific gravity of sands was found to be 2.64. The coarser size sand, Soil 1 $\left(D_{50}=1.5 \mathrm{~mm}\right)$, has soil particle diameter values ranging from 1 to $2 \mathrm{~mm}$. The finer size sand, Soil 3
Fig. 5 Reinforcement placed and attached to clamper
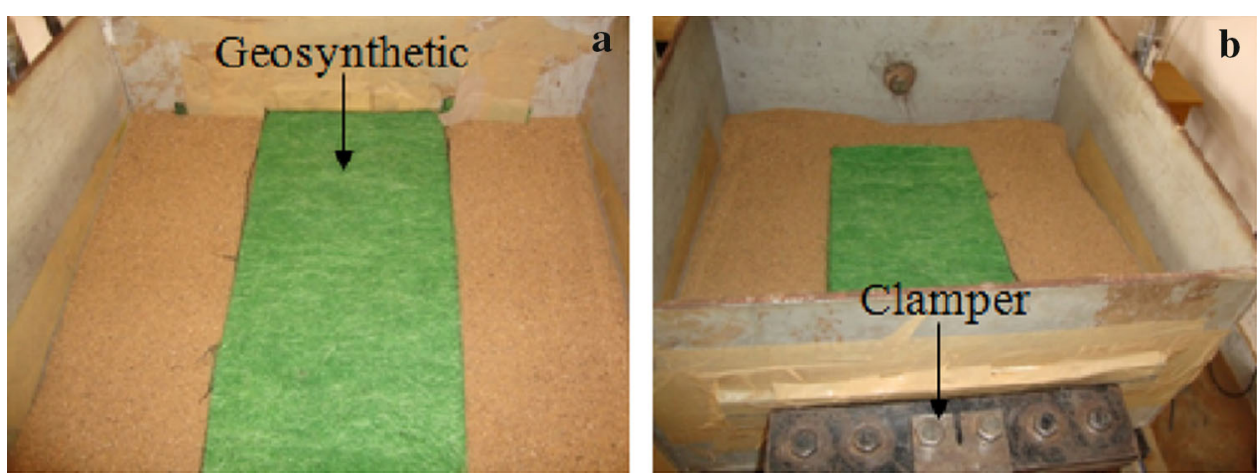
$\left(D_{50}=0.22 \mathrm{~mm}\right)$, has soil particle diameters values range from 0.09 to $0.5 \mathrm{~mm}$. All the soils are classified as poorly graded sands (SP) according to unified soil classification system [37]. Microscopic views of the different grades of soils are shown in Fig. 7. From the figure it can be seen that the sand particles are of round/sub angular shape and surface is smooth.

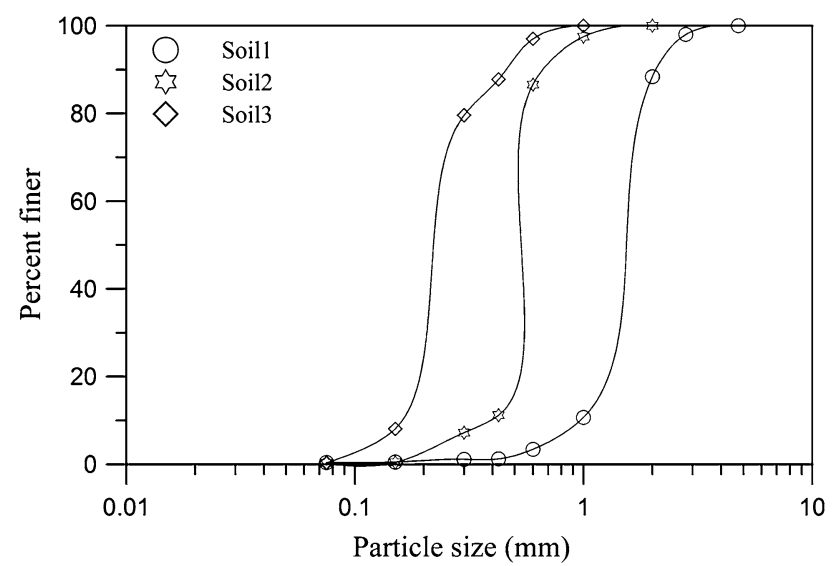

Fig. 6 Grain size distribution curves of soils used

Table 1 Physical properties of three soils used in study

\begin{tabular}{llll}
\hline Properties & Soil1 & Soil2 & Soil3 \\
\hline$G$ & 2.64 & 2.64 & 2.64 \\
$D_{10}(\mathrm{~mm})$ & 1 & 0.4 & 0.16 \\
$D_{30}(\mathrm{~mm})$ & 1.2 & 0.46 & 0.2 \\
$D_{50}(\mathrm{~mm})$ & 1.5 & 0.5 & 0.22 \\
$D_{60}(\mathrm{~mm})$ & 1.6 & 0.51 & 0.25 \\
$C_{u}$ & 1.6 & 1.27 & 1.56 \\
$C_{c}$ & 0.9 & 1.03 & 1 \\
Classification (USCS) & $\mathrm{SP}$ & $\mathrm{SP}$ & $\mathrm{SP}$ \\
$\gamma_{d, \text { max }}\left(\mathrm{kN} / \mathrm{m}^{3}\right)$ & 16.6 & 16.3 & 16.7 \\
$\gamma_{d, \text { min }}\left(\mathrm{kN} / \mathrm{m}^{3}\right)$ & 14.8 & 14.5 & 14.6 \\
$(\phi)$ at $\mathrm{RD} 70 \%$ & 37.7 & 34.8 & 33.1 \\
\hline
\end{tabular}

\section{Geosynthetics}

Three types of geosynthetics were used. They are nonwoven geotextile (GT1), woven geotextile (GT2) and geogrid (GT3) as shown in Fig. 8. The biaxial geogrid made of oriented polymer were used in the study. It had square shaped apertures with opening size of $35 \mathrm{~mm} \times 35 \mathrm{~mm}$ (Fig. 9). The tensile properties of geotextile were determined as per ASTM D4595 [38] and mass per unit area of the materials were determined as per ASTM D5261 [39] and are presented in Table 2. The tensile load-strain response of GT1, GT2 and GT3 are shown in Fig. 10. From Table 2 and Fig. 10 It can be observed that the nonwoven geotextile (GT1) and woven geotextile (GT2) are having almost same tensile strength with different elongation at failure but geogrid (GT3) having different tensile strength and elongation at failure.

\section{Test Results and Discussion}

\section{Direct Shear Test Results}

A series of direct shear tests, according to ASTM D3080 [30] and ASTM D5321 [7], were performed in the study using three types of granular soils (soil1, soil2 and soil3) and two types of geotextiles (GT1 and GT2). All the soil specimens were prepared at $70 \%$ relative density (RD) using sand raining technique. The height of fall required to achieve desire relative density was determined by trail tests. The samples collected, while preparing the specimens, showed the $\pm 2 \%$ variations in the unit weights. All the tests were conducted at $4.57 \mathrm{~mm} / \mathrm{min}$ displacement rate and under a normal stress of $50 \mathrm{kPa}$.

Results obtained from direct shear tests on three soils and modified shear tests on three different soils with non-woven geotextile (GT1) are shown in Fig. 11. The peak shear resistance occurred at the shear displacement of 3-6 mm and $6-10 \mathrm{~mm}$ for unreinforced and reinforced specimens, respectively. From the Fig. 11 it is observed that soil-soil peak shear stress are $32.09,28.36$ and $26.88 \mathrm{kPa}$ for
Fig. 7 Microscopic view of soil1, soil2 and soil3

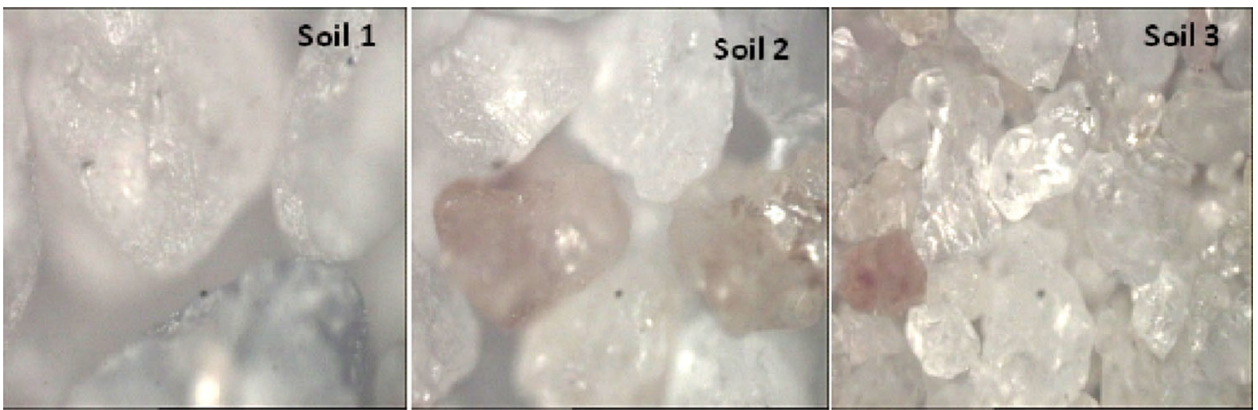


Fig. 8 Geosynthetics used in study
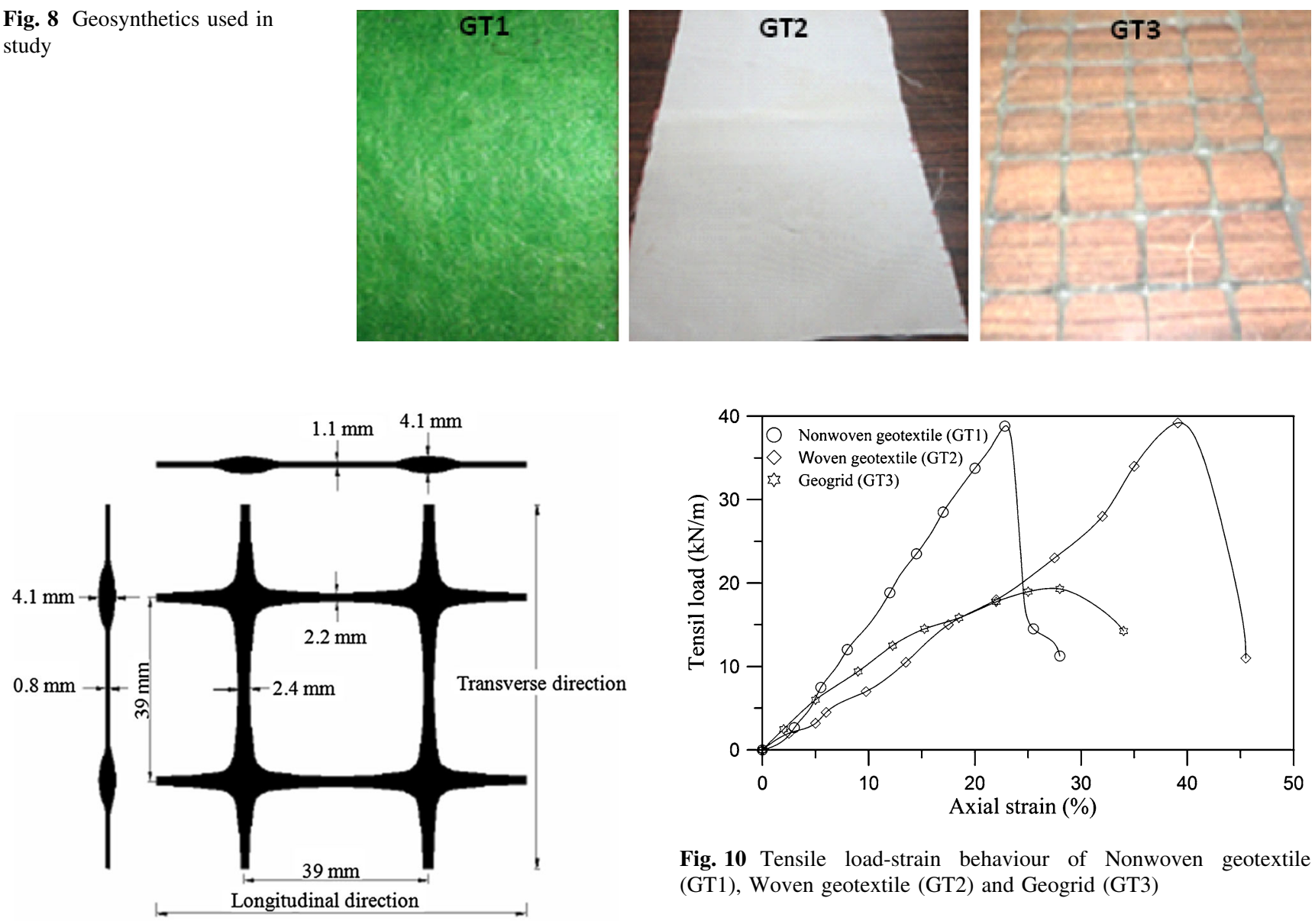

Fig. 9 Geometry of the geogrid

Table 2 Properties of geosynthetics used in study

\begin{tabular}{llll}
\hline Properties & $\begin{array}{l}\text { Nonwoven } \\
\text { geotextile (GT1) }\end{array}$ & $\begin{array}{l}\text { Woven } \\
\text { Geotextile } \\
\text { (GT2) }\end{array}$ & $\begin{array}{l}\text { Geogrid } \\
\text { (GT3) }\end{array}$ \\
\hline Mass per unit area $\left(\mathrm{g} / \mathrm{m}^{2}\right)$ & 698 & 250.4 & 332 \\
Tensile strength $(\mathrm{kN} / \mathrm{m})$ & 38.8 & 39.2 & 19.3 \\
Elongation at break $(\%)$ & 22.8 & 39.13 & 28 \\
\hline
\end{tabular}

unreinforced soil1 $\left(D_{50}=1.5 \mathrm{~mm}\right)$, soil2 $\left(D_{50}=0.5 \mathrm{~mm}\right)$ and soil3 $\left(D_{50}=0.22 \mathrm{~mm}\right)$ respectively. The corresponding soil-geosynthetic (GT1) peak shear stresses are 16.75, 15.57 and $14.67 \mathrm{kPa}$, respectively, for three different soils, in order. From these peak stress values, it can be noted that the response follows increasing trend with mean particle size of soil $\left(D_{50}\right)$. Figure 11 clearly provides the comparison of all modified direct shear test results for three different soils with non-woven geotextile (GT1).

Figure 12 presents the results similar to Fig. 11, but with woven geotextile (GT2). In this case, soil-geosynthetic (GT2) peak shear stress for different soils: soil1 $\left(D_{50}=1.5 \mathrm{~mm}\right), \quad$ soil2 $\left(D_{50}=0.5 \mathrm{~mm}\right) \quad$ and soil3

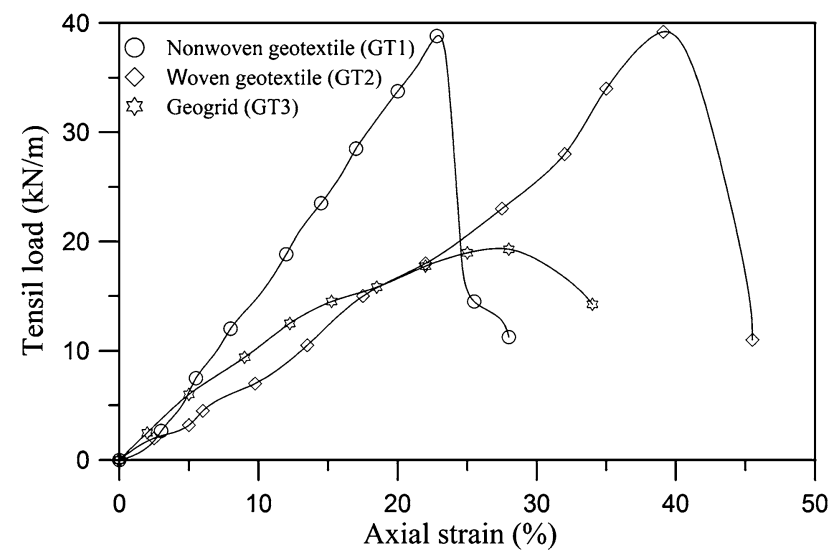

Fig. 10 Tensile load-strain behaviour of Nonwoven geotextile (GT1), Woven geotextile (GT2) and Geogrid (GT3)

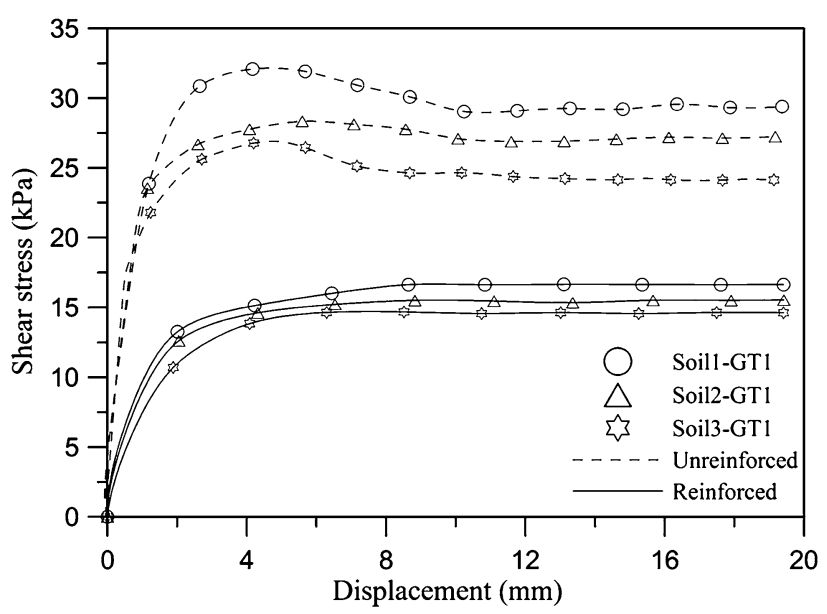

Fig. 11 Direct shear test (unreinforced) and modified direct shear test (reinforced) results of all soils with GT1

$\left(D_{50}=0.22 \mathrm{~mm}\right)$ are $16.62,14.27$ and $13.3 \mathrm{kPa}$ and respectively. These peak stress values are lower than that of non-woven geotextile (GT1) case. This implies that nonwoven geotextile facilitated good interaction with neighbouring soil which may be attributed to its texture. However, for the case of coarser size soil (soil1) the difference between the peak shear stress values for both GT1 


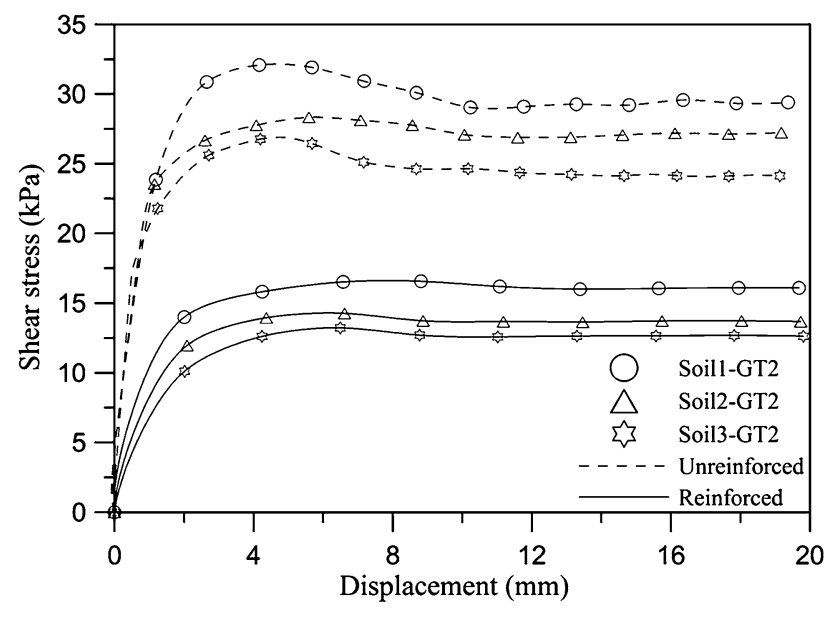

Fig. 12 Direct (soil-soil) and modified direct shear test (soil-GT) results of all soils with GT2

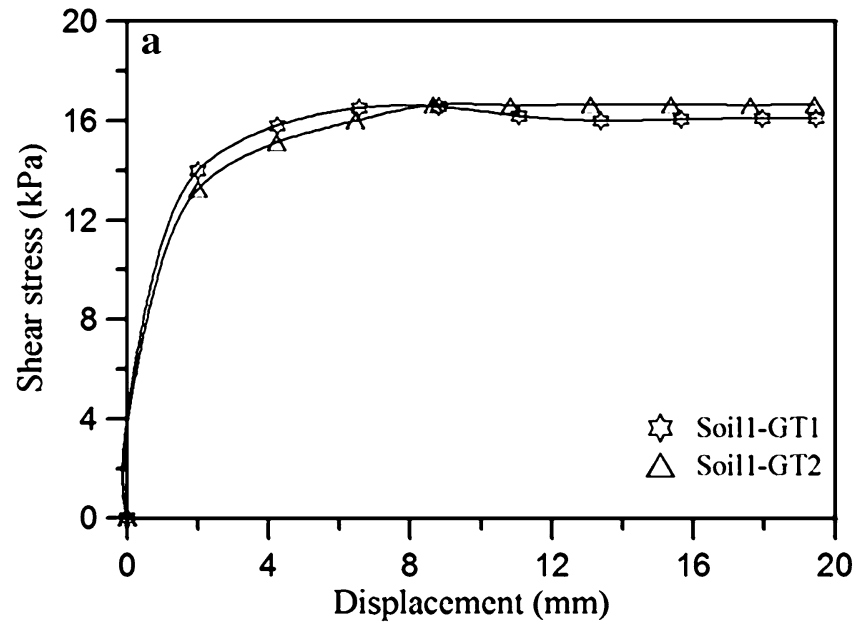

and GT2 is not very significant (Fig. 13a), which is attributed to the larger mean particle size $\left(D_{50}=1.5 \mathrm{~mm}\right)$. This shows that the larger particle (soil1) could able to penetrate both woven and nonwoven geotextile thereby giving almost same peak shear stress. In contrast, fine particle (soil3) cannot able to penetrate the woven geotextile, but can able to stick to nonwoven geotextile thereby exhibited more stress than that of woven geotextile (Fig. 13c). Soil2 $\left(D_{50}=0.5 \mathrm{~mm}\right)$ having intermediate particle size shows intermediate behaviour (Fig. 13b).

\section{Efficiency Factors}

Using peak shear stress values obtained from experimental data, friction angle $(\phi)$ for different soils and interfacial friction angle $\left(\delta_{\mathrm{GT}}\right)$ for different soils-geosynthetics

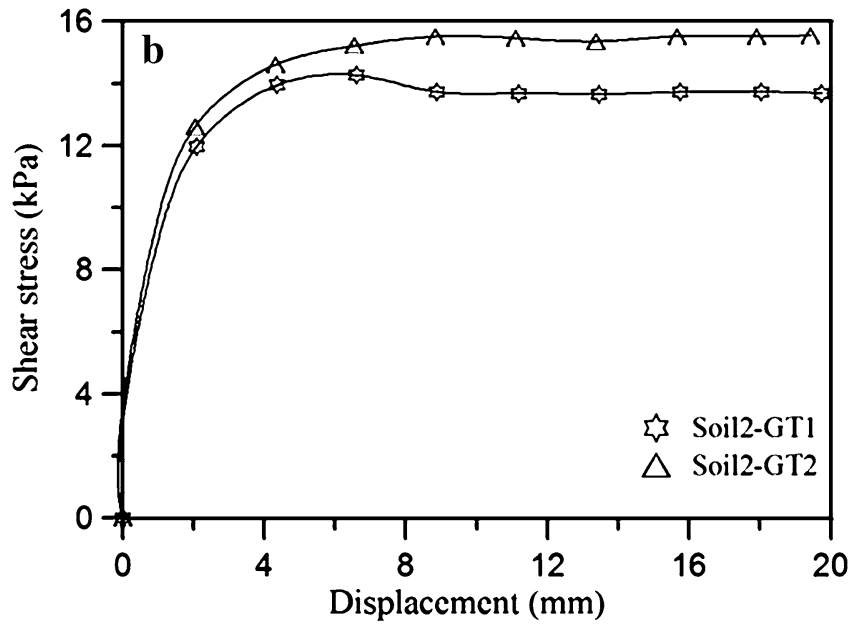

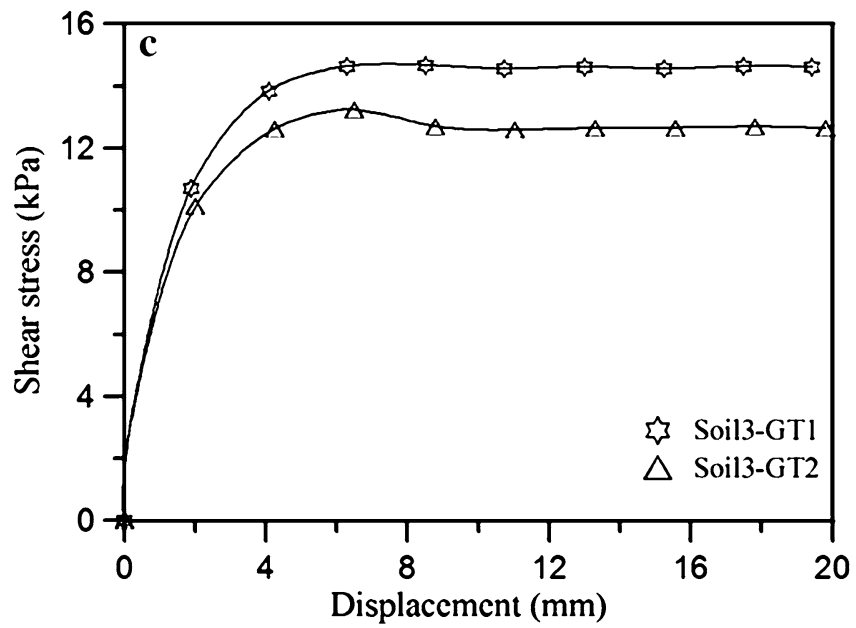

Fig. 13 Modified direct shear test results for soils/geotextile: influence of geotextiles 
combinations were evaluated by as per Mohr-Coulomb principle (Eqs. 1 and 2).

$$
\begin{gathered}
\tau_{\mathrm{p}}=c+\sigma_{n}^{\prime} \tan (\phi) \\
\tau_{\mathrm{pm}}=c+\sigma_{n}^{\prime} \tan \left(\delta_{\mathrm{GT}}\right)
\end{gathered}
$$

where, $\tau_{\mathrm{p}}$ is the peak shear stress from direct shear test (soil-soil), $\tau_{\mathrm{pm}}$ is the peak shear stress from modified direct shear test (soil-Geosynthetic), $c=$ soil cohesion ( $c=0$ for granular soil), $\sigma_{n}^{\prime}$ is the effective normal stress $(=50 \mathrm{kPa}$ for all the tests), $\phi$ is the frictional angle of sand and $\delta_{\mathrm{GT}}$ is the interfacial frictional angle between soil and geosynthetic in direct shear test.

The friction efficiency factors $\left(E_{\phi}\right)$ were evaluated from the calculated values of $\phi$ and $\delta_{\mathrm{GT}}$ using Eq. 3 .

$E_{\phi}=\left(\tan \delta_{\mathrm{GT}}\right) /(\tan \phi)$

The internal friction angle $(\phi)$, interfacial friction angle $\left(\delta_{\mathrm{GT}}\right)$ and efficiency factor $\left(E_{\phi}\right)$ evaluated for different soils with different geosynthetics are presented in Table 3.

When comparing the interfacial friction angle $\left(\delta_{\mathrm{GT}}\right)$ values for the two geosynthetics, a difference of approximately 1.09, 8.1 and $9.73 \%$ for different soils (soil1 to 3 in order), respectively, is observed. The higher $\delta_{\mathrm{GT}}$ values for non-woven geotextile (GT1) may be attributed to its rough texture relative to the smooth texture of woven geotextile (GT2). The surface roughness of nonwoven geotextile is the reason for the increasing resistance

From the Table 3 it can also be noted that soil 1 exhibited 7.55 and $13.14 \%$ higher $\delta_{\mathrm{GT}}$ values with GT1, when compared to $\delta_{\mathrm{GT}}$ values for soil 2 and soil 3 respectively. For GT2 these variations are 15.02, and $22.8 \%$. With this observation it can be stated that the type of soil has significant role on interface friction angle values. From the results reported here, it is also noted that the woven geotextile (GT2) results are more affected with soil variation, the range being $15-23 \%$ in comparison to $7-13 \%$ for nonwoven geotextile (GT1). Further, from all the tests, the lowest soil-geosynthetic interface friction angle value obtained was $14.9^{\circ}$, which corresponds to soil3 $\left(D_{50}=0.22\right) /$ geotextile GT2 (smoother surface), while the highest value was $18.5^{\circ}$, which corresponds to soill $\left(D_{50}=1.5\right) /$ geotextile GT1 (having the rougher surface). Therefore, the structure of the geosynthetics and soil particle size play a very important role in the soil-geosynthetic interface resistance.

However, in contrast to the discussion on the interfacial friction angles, variation in efficiency factors $\left(E_{\phi}\right)$ for different soils is not very significant for a selected geosynthetic material. The fact here is that the efficiency factors are representing the interfacial friction values of different types of soils normalised with the frictional angle values of the same soil. But different efficiency factors $\left(E_{\phi}\right)$ for different geosynthetics are observed from the values presented in Table 3. An average $E_{\phi}$ for non-woven geotextile (GT1) being 0.45 while the same for woven geotextile (GT2) it is 0.41 . The similar range of efficiency factors has been reported by Hsieh et al. [29].

The variation of interfacial friction angle $\left(\delta_{\mathrm{GT}}\right)$ with $D_{50}$ of soil is depicted in Fig. 14. For the materials tested and for the test conditions considered, it could be observed that the $\delta_{\mathrm{GT}}$, increases linearly with increase in $D_{50}$ of soil for the both woven and nonwoven geotextile. This linear relationship can be approximated to find the interfacial friction angle $\left(\delta_{\mathrm{GT}}\right)$ for different type of granular soil with these particular geosynthetics materials.

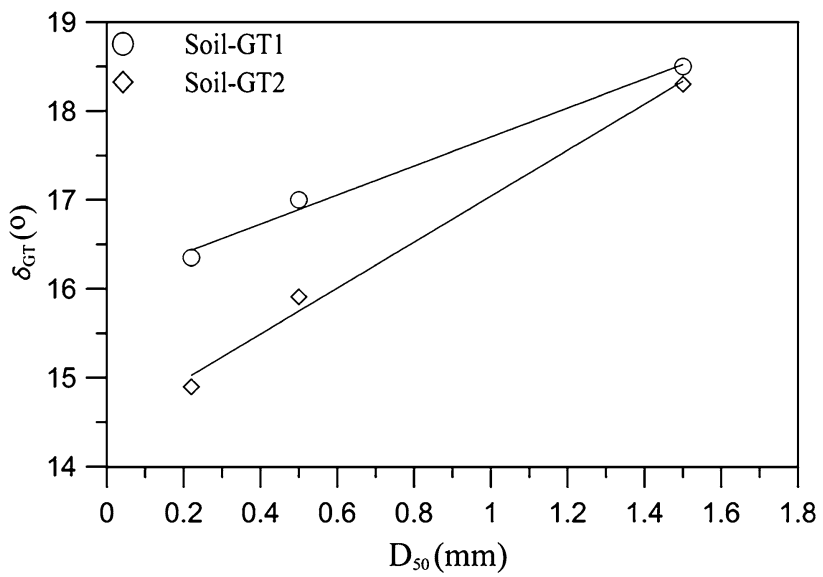

Fig. 14 Variation of interfacial friction angle $\left(\delta_{\mathrm{GT}}\right)$ with $D_{50}$ of soil
Table 3 Internal friction angle $(\phi)$, interfacial friction angle $\left(\delta_{\mathrm{GT}}\right)$ and efficiency factor $\left(E_{\phi}\right)$ values

\begin{tabular}{lllllll}
\hline Soil type & $\phi\left(^{\circ}\right)$ & \multicolumn{2}{l}{ Non-woven geotextile $(\mathrm{GT} 1)$} & & \multicolumn{2}{l}{ Woven geotextile $(\mathrm{GT} 2)$} \\
& & $\delta_{\mathrm{GT}}\left({ }^{\circ}\right)$ & $E_{\phi}=\tan \delta_{\mathrm{GT}} / \tan \phi$ & & $\delta_{\mathrm{GT}}\left(^{\circ}\right)$ & $E_{\phi}=\tan \delta_{\mathrm{GT}} / \tan \phi$ \\
\hline Soil1 & 37.7 & 18.5 & 0.43 & 18.3 & 0.42 \\
Soil2 & 34.8 & 17 & 0.44 & 15.91 & 0.4 \\
Soil3 & 33.1 & 16.35 & 0.45 & 14.9 & 0.41 \\
\hline
\end{tabular}




\section{Pullout Test Results}

A series of pullout tests, according to ASTM D 6706 [14], were performed in this study using three types of granular soils (soil1, soil2 and soil3) and two types of geotextiles (GT1 and GT2) and one type of geogrid (GT3). All the soil specimens were prepared at $70 \%$ relative density using sand raining method. All the tests were conducted at a displacement rate of $4.567 \mathrm{~mm} / \mathrm{min}$ and under normal stress of $20 \mathrm{kPa}$. The length of geosynthetics $(L)$ embedded in soil mass is $300 \mathrm{~mm}$. The effective length $\left(L_{\mathrm{e}}\right)$ of geosynthetics has been calculated by deducting the pullout deformation/displacement from the total embedment length. As the extensibility measurements of the geogrid members are not available due to limitation of tests setup used in the present study, the displacement of the reinforcement is considered for evaluating the active length. Typical pullout test results for the geotextile/geogrid with soil are presented in Figs. 15, 16 and 17 for different geosynthetic materials GT1, GT2 and GT3, respectively. The peak pullout resistances, for soil1, soil2 and soil3 with nonwoven geotextile (GT1) are observed to be 8.72, 6.38 and $5.37 \mathrm{kN} / \mathrm{m}$, respectively, as shown in Fig. 15. Similarly, the peak pullout resistance observed 7.97, 5.36 and $4.42 \mathrm{kN} / \mathrm{m}$ for soils1-3 with woven geotextile (GT2) is shown in Fig. 16 and the values are 21.89, 18.23 and 17.30 $\mathrm{kN} / \mathrm{m}$ for soils1-3 with GT3 (Fig. 17). It could be observed that the pullout resistance of geotextile/geogrid is significantly influenced by the soil types. This behaviour can be explained by referring to the soil particle size. All particles in Soil3 have an equivalent diameter less than $0.5 \mathrm{~mm}$, while for Soil1, $50 \%$ of particles are between 1.5 and $2 \mathrm{~mm}$ in diameter with a maximum particle size of $2 \mathrm{~mm}$. Soil1 $\left(D_{50}=1.5 \mathrm{~mm}\right) /$ nonwoven geotextile (GT1) exhibited $3.35 \mathrm{kN} / \mathrm{m}$ i.e. $(62.38 \%)$ more peak pullout than that

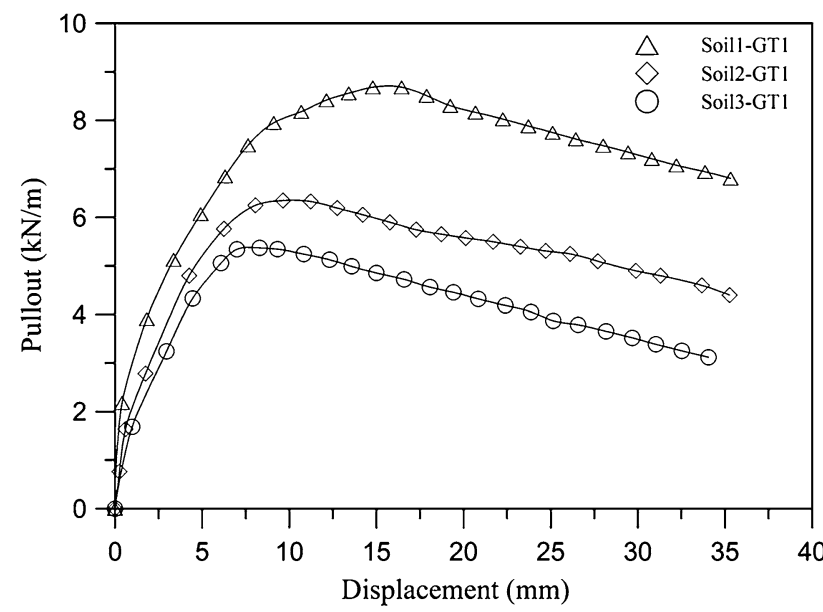

Fig. 15 Pull out-displacement response of soil-nonwoven geotextile (GT1)

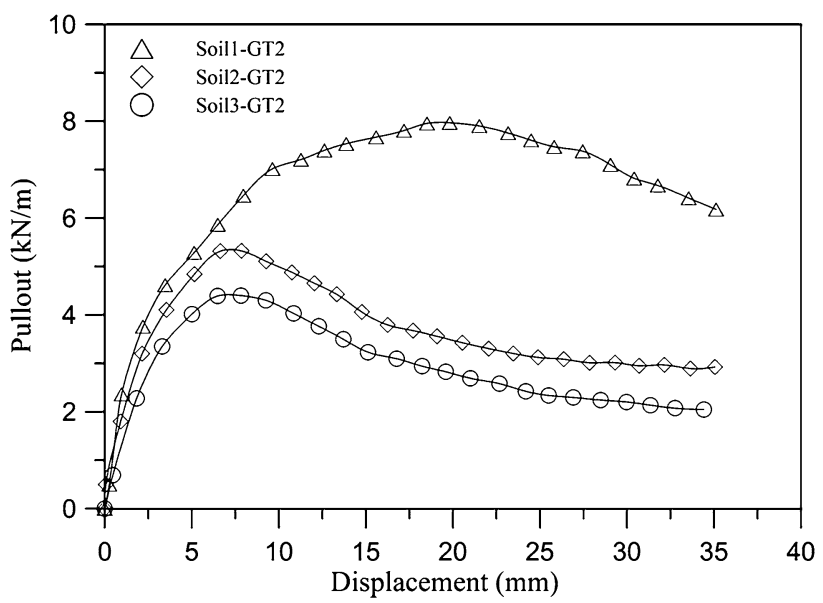

Fig. 16 Pull out-displacement response of soil-woven geotextile (GT2)

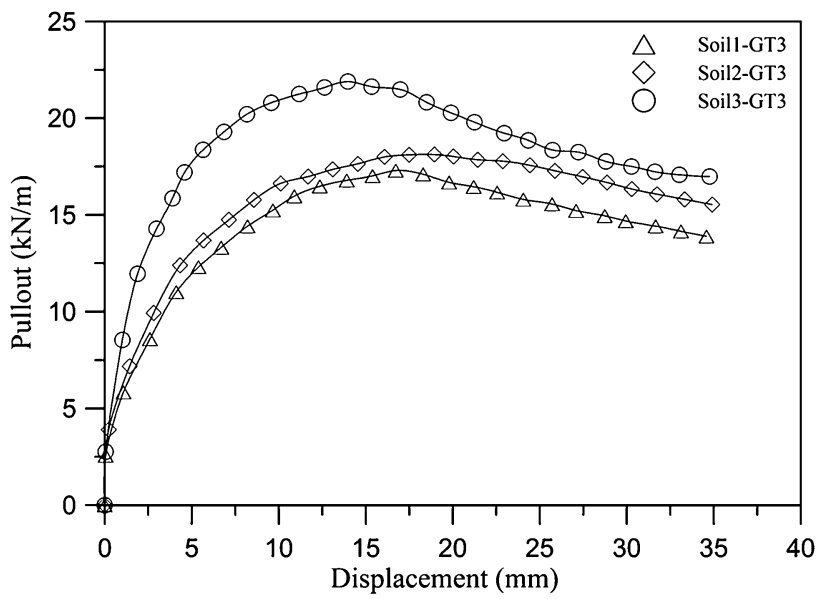

Fig. 17 Pull out-displacement response of soil-geogrid (GT3)

of soil3 $\left(D_{50}=0.5 \mathrm{~mm}\right) /$ nonwoven geotextile (GT1). Soil1 $\left(D_{50}=1.5 \mathrm{~mm}\right) /$ woven geotextile $(\mathrm{GT} 2)$ exhibited $3.55 \mathrm{kN} / \mathrm{m}$ i.e. $(80.31 \%)$ more peak pullout than that of soil3 $\left(D_{50}=0.5 \mathrm{~mm}\right) /$ woven geotextile $(\mathrm{GT} 2)$. It is concluded that soill/geotextile exhibited higher peak pullout resistance than soil3/geotextile.

From Fig. 18, it is interest to note that the influence of geotextile types (GT1 and GT2) shows less significance for Soil1 $\left(D_{50}=1.5 \mathrm{~mm}\right)$, whereas for soil2 and soil3, nonwoven geotextile exhibited higher resistance than that of woven geotextile. Similar behaviour observed for soil/ nonwoven geotextile through direct shear tests, which is in general agreement with the pullout results. Soil1 $\left(D_{50}\right.$ $=1.5 \mathrm{~mm}) /$ geogrid $(\mathrm{GT} 3)$ exhibited $4.49 \mathrm{kN} / \mathrm{m}$ i.e. $(26.53 \%)$ more peak pullout than that of soil3 $\left(D_{50}\right.$ $=0.5 \mathrm{~mm}$ )/geogrid (GT3). The pullout resistance observed for soil/geogrid is much higher than the soil/geotextile. The higher pullout resistance exhibited is associated with the two different behaviors of geogrid. First, the increase in 

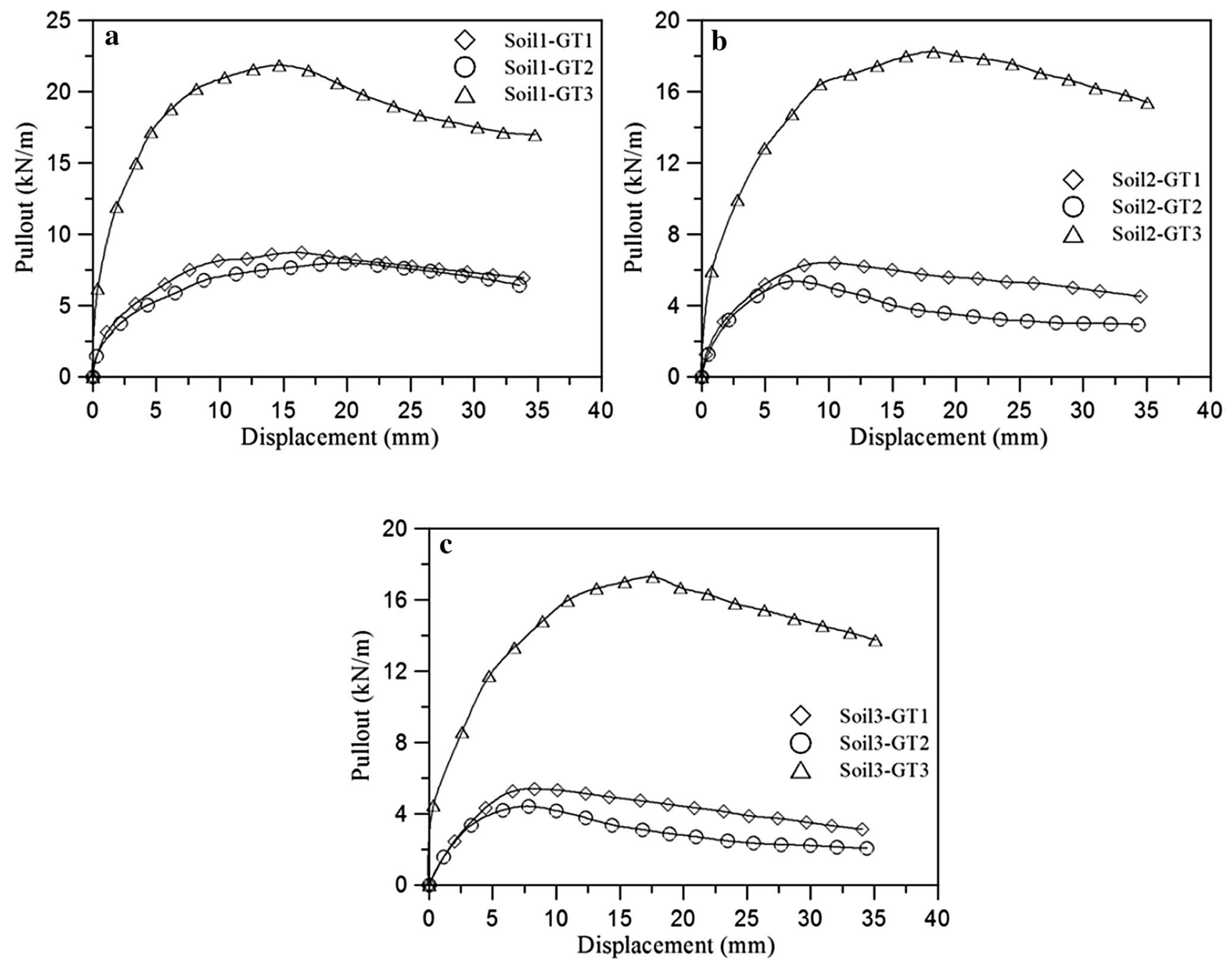

Fig. 18 Pull out-displacement response of soil-geotextile (GT): influence of geotextiles

pullout resistance could be a result of the frictional resistance developed along the surface of the longitudinal and transverse ribs of the geogrid. The second reason is the passive resistance mobilizes against the transverse ribs of the geogrid. Although the pullout resistance observed for soil/geogrid is much higher than the soil/geotextile but the influence of $\left(D_{50}\right)$ shows less effect on peak pullout resistance. This might be due to aperture opening size of geogrid (i.e. $35 \times 35 \mathrm{~mm}$ ) is much larger that the particle size of soil used in the present study. All three types of soils can easily able to trapped into the aperture of geogrid and lead to lesser influence on over all pullout resistance.

Interfacial friction angle $\left(\phi_{r}\right)$ and interaction coefficients $\left(C_{i}\right)$ were determined using the Eqs. (4) and (5) respectively, and tabulated in Table 4. The same equations based on continuum approach were adopted even for geogrid reinforcement also.

$T /\left(2 L_{e}\right)=\sigma_{n}^{\prime} \tan \left(\phi_{r}\right)$
$T=2 C_{i} L_{e} \sigma_{n}^{\prime} \tan (\phi)$

where, $T$ is the pullout resistance per unit width $(\mathrm{kN} / \mathrm{m}), \phi_{r}$ is the interfacial friction angle (deg.), $L_{e}$ is the $L$-peak pullout deformation (m), $\sigma_{n}^{\prime}$ is the effective normal stress in the geosynthetic $\left(\mathrm{kN} / \mathrm{m}^{2}\right)$, and $C_{i}$ is the interaction coefficient, $\phi$ is the soil friction angle (deg.).

The pullout interaction coefficients $\left(C_{i}\right)$ are found to be in the range of $0.62-1.72$ for different tests conditions. The similar behaviour has been reported by Hsieh et al. [29]. It is also clearly seen that interfacial friction angle $\left(\phi_{r}\right)$ of soill/geogrid (GT3) is higher than that of soil3/geogrid (GT3), soil1/nonwoven geotextile (GT1) is higher than that of soil3/nonwoven geotextile (GT1) and soil1/woven geotextile (GT3) is higher than that of soil3/woven geotextile (GT3) as tabulated in Table 4. This is only because of soil1 has larger particle size i.e. $\left(D_{50}=1.5 \mathrm{~mm}\right)$ than soil3 $\left(D_{50}=0.22 \mathrm{~mm}\right)$. Soil2 $\left(D_{50}=0.5 \mathrm{~mm}\right)$ having intermediate particle size shows intermediate behaviour. 
Table 4 Interfacial frictional angles of used geosynthetics-sand

\begin{tabular}{llllll}
\hline Soil types & Type of geotextile & $\sigma_{n}^{\prime}(\mathrm{kPa})$ & Pullout shear stress $(\mathrm{kPa})$ & Interface frictional angle $\left(\phi_{r}\right)$ & Coefficient of interaction $\left(C_{i}\right)$ \\
\hline Soil1 & (GT1) & 20 & 15.33 & 37.47 & 0.99 \\
& (GT2) & 20 & 14.27 & 35.5 & 0.94 \\
& (GT3) & 20 & 38.27 & 62.4 & 1.65 \\
Soil2 & (GT1) & 20 & 10.62 & 27.98 & 0.80 \\
& (GT2) & 20 & 8.60 & 23.26 & 0.68 \\
& (GT3) & 20 & 33.31 & 59.02 & 1.69 \\
Soil3 & (GT1) & 20 & 9.23 & 24.77 & 0.74 \\
& (GT2) & 20 & 7.58 & 20.75 & 0.62 \\
& (GT3) & 20 & 30.64 & 56.86 & 1.72 \\
\hline
\end{tabular}

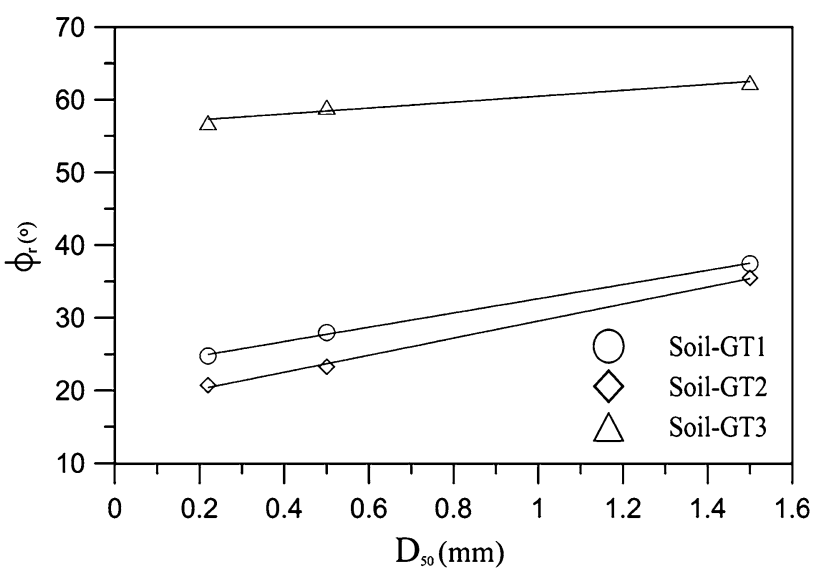

Fig. 19 Variation of interfacial friction angle $\left(\phi_{r}\right)$ with $D_{50}$ of soil

The variation of interfacial friction angle $\left(\phi_{r}\right)$ with $D_{50}$ of soil for pullout test is depicted in Fig. 19. Based on the limited number of tests conducted and limitations owing to the materials and test conditions, it could be observed that the $\phi_{r}$, increases linearly with increase in $D_{50}$ of soil for the both geotextile and geogrid. This linear relationship can be used to find the interfacial friction angle $\left(\phi_{r}\right)$ for different type of granular soil with these particular geosynthetics materials. However, this conclusion is true for the materials tested and the test conditions considered. Therefore, further more studies are essential for establishing a generalized observation.

\section{Conclusions}

The study presented the influence of soil particle size and geosynthetics structure on the behaviour of soil-geosynthetics interface through experimental investigations. The results are presented in terms of peak shear resistance, peak pullout resistance, interface friction angle, efficiency factors and interaction coefficient. The study reveals the following observations:
- Soil particle size has an important influence on the soilgeosynthetic interface friction angle. For the range of materials tested, the soils with larger average soil particle sizes (i.e. higher $D_{50}$ ) show an increase in the soil-geosynthetic interface resistance.

- Geosynthetic surfaces allowing the penetration of soil particles into the geosynthetic (e.g., nonwoven geotextiles) are depicted with higher soil-geosynthetic interface friction angle values than that of woven geotextile.

- The geogrid gives more pullout resistance than that of woven and nonwoven geotextiles for all the soils considered which is due to the passive resistance along the ribs of the geogrid material.

- Both the geosynthetics (i.e. GT1 and GT2) show similar shear behaviour for larger particle size, whereas for smaller particle size, the nonwoven geotextile exhibits more interfacial friction angle in both direct shear and pullout tests.

- Based on the limited number of tests conducted and limitations owing to the materials and test conditions, it can be observed that the interface friction angles, from both direct shear and pullout tests, are linear varied with the increase in mean particle size of soils $\left(D_{50}\right)$.

The conclusions drawn are for the range of materials tested and the test conditions considered. As the present study performed only limited number of tests without considering the geosynthetics extensibility aspects, further more sophisticated studies are essential for establishing a generalized observations and design recommendations.

\section{References}

1. Shukla SK (2002) Geosynthetics and their applications. Thomas Telford Publishing, London

2. Shukla SK, Yin JH (2006) Fundamentals of geosynthetic Engineering. Taylor and Francis, London

3. Shukla SK (2012) Handbook of geosynthetic Engineering, 2nd edn. ICE Publishing, London 
4. Liu CN, Gilbert RB (2003) Simplified method for estimating geosynthetic loads in landfill liner side slopes during filling. Geosynth Int 10(1):24-33

5. Palmeira EM, Viana HNL (2003) Effectiveness of geogrids as inclusions in cover soils of slopes of waste disposal areas. Geotext Geomembr 21(5):317-337

6. Elias V, Christopher BR (1996) Mechanically stabilized earth walls and reinforced soil slopes-design and construction guidelines. FHWA Demonstration Project 82. Federal Highway Administration, McLean, VA, USA

7. ASTM D5321 (2002) Standard test method for determining the coefficient of soil and geosynthetic or geosynthetic and geosynthetic friction by the Direct Shear Method. ASTM Designation: D5321-02, ASTM, USA

8. Lopes PC, Lopes MJ, Lopes ML (2001) Shear behaviour of geosynthetics in the inclined plane test influence of soil particle size and geosynthetic structure. Geosynth Int 8:327-342

9. Wu W, Wick H, Ferstl F, Aschauer F (2008) A tilt table device for testing geosynthetic interfaces in centrifuge. Geotext Geomembr 26(1):31-38

10. Richards EA, Scott JD (1985) Soil geotextile frictional properties. Second Canadian symposium on geotextiles and geomembranes, Edmonton, 13-24

11. Lee KM, Manjunath VR (2000) Soil-geotextile interface friction by direct shear tests. Can Geotech J 37:238-252

12. Mahmood A, Zakaria N, Ahmad F (2000) Studies on geotextile/soil interface shear behaviour. Electron J Geotech Eng, 5

13. Bergado DT, Ramana GV, Sia HI, Varun HI (2006) Evaluation of interface shear strength of composite liner system and stability analysis for a landfill lining system in Thailand. Geotext Geomembr 24:371-393

14. ASTM D6706 (2001) Standard test method for measuring geosynthetic pullout resistance in soil. ASTM Designation: D6706-01, ASTM, USA

15. Giroud JP (1986) From geotextiles to geosynthetics: a revolution in geotechnical engineering. In: Proceedings of the 3rd international conference on geotextiles, Vienna, Austria, Vol 1: 1-18

16. Bergado DT, Sampaco, CL, Shivashankar R, Alfaro MC, Anderson LR, Balasubramaniam AS (1991) Performance of a welded wire wall with poor quality backfills on soft clay. ASCE Geotechnical, 908-922. Special Publication No. 27

17. Touahamia M, Sivakumar V, McKelvey D (2002) Shear strength of reinforced-recycled material. Constr Build Mater 16:331-339

18. Jewell RA, Milligan GWE, Sarsby RW, Dubois D (1984) Interaction between soil and geogrids, polymer grid reinforcement, Thomas Telford Ltd., In: Proceedings of a conference held in London, United Kingdom, March 1984, pp 18-30

19. Goodhue MJ, Edil TB, Benson CH (2001) Interaction of foundry sands with geosynthetics. J Geotech Geoenviron Eng ASCE 124(4):353-362

20. Sugimoto M, Alagiyawanna AMN (2003) Pullout behaviour of geogrid by test and numerical analysis. J Geotech Geoenviron Eng ASCE 129(4):361-371

21. Desai FCS, El-Hoseiny KE (2005) Prediction of field behaviour of reinforced soil wall using advanced constitutive model. J Geotech Geoenviron Eng ASCE 131(6):729-739

22. Moraci N, Gioffre D (2006) A simple method to evaluate the pullout resistance of extruded geogrids embedded in a compacted granular soil. Geotext Geomembr 24(3):198-199
23. Palmeira EM, Milligan GWE (1989) Scale and other factors affecting the results of pull-out tests of grid buried in sand. Géotechnique 11(3):511-524

24. Moraci N, Recalcati PG (2006) Factors affecting the pullout behaviour of extruded geogrids embedded in compacted granular soil. Geotext Geomembr 24(22):220-242

25. Palmeira EM (2009) Soil-geosynthetic interaction: modelling and analysis. Geotext Geomembr 27(5):368-390

26. Toufigh V, Saeid F, Toufigh V, Ouria A, Desai CS, Saadatmanesh H (2013) Laboratory study of soil-CFRP interaction using pullout test. Geomech Geoeng 9(3):208-214

27. Cazzuffi D, Moraci N, Calvarano LS, Cardile G, Gioffre D, Recalcati P (2014) European experience in pullout tests: Part 2-The influence of vertical effective stress and of geogrid length on interface behaviour under pullout conditions. Geosynthetics 32(2):40-50

28. Moraci N, Cardile G, Gioffre D, Mandaglio MC, Calvarano LS, Carbone L (2014) Soil geosynthetic interaction: design parameters from experimental and theoretical analysis. Transp Infrastruct Geotechnol 1(2): 165-227

29. Hsieh CW, Chen GH, Jeng-Han W (2011) The shear behaviour obtained from the direct shear and pullout tests for different poor graded Soil-geosynthetic systems. J Geoeng 6:15-26

30. ASTM D3080 (2011) Standard test method for direct shear test of soils under consolidated drained conditions. ASTM International, West Conshohocken, PA

31. Lopes ML, Silvano R (2010) Soil/geotextile interface behaviour in direct shear and pullout movements. GeotechGeol Eng 28:791-804

32. Prashanth V, Krishna AM (2016) Pullout tests using modified Direct Shear Test Setup for measuring soil-geosynthetic interaction parameters, International Journal of Geosynthetics and Ground Engineering. (submitted)

33. ASTM D6913-04(2009) Standard Test Methods for Particle-Size Distribution (Gradation) of Soils Using Sieve Analysis.American Society for Testing and Materials, West Conshohocken, PA

34. ASTM D4253 (2006) Standard test methods for maximum index density and unit weight of soils and calculation of relative density. ASTM International, West Conshohocken, PA, 2006, Vol. 04. 08

35. ASTM D4254 (2006) Standard test methods for minimum index density and unit weight of soils and calculation of relative density. ASTM International, West Conshohocken, PA, 2006, Vol. 04. 08

36. ASTM standard D0854 (2006) Standard test methods for specific gravity of soil solids by water pycnometer. ASTM international, West Conshohocken, PA, 2006, vol. 04.09

37. ASTM D 2487 (2006) Standard practices for classification of soils for engineering purposes (Unified Soil Classification System). ASTM International, West Conshohocken, PA, 2006, Vol. 04. 08

38. ASTM D4595 (2009) standard test method for tensile properties of geotextiles by the wide-width strip method. American Society for Testing and Materials, West Conshohocken, PA

39. ASTM D5261 (1996) Standard test method for measuring mass per unit area of geotextiles. American Society for Testing and Materials, West Conshohocken, PA 